\title{
Evaluation of the chemical composition and bioactivity of essential oils from Cinnamomum camphora (L.) J.PRESL. (Lauraceae), Piper nigrum L. (Piperaceae) and Stemona japonica (MIQ.) (Stemonaceae) against Oryzaephilus surinamensis (LINNAEUS, 1758) (Coleoptera: Silvanidae)
}

\author{
Tufail Ahmed Wagan, Xiang Li, HongXia HuA, Wanlun CAi ${ }^{*}$
}

Hubei Insect Resources Utilisation and Sustainable Pest Management Key Laboratory, College of Plant Science and Technology, Huazhong Agricultural University, Wuhan 430070, China

\begin{abstract}
Oryzaephilus surinamensis is a serious insect pest of many stored products. Repellency and fumigation tests were performed to manage it. Essential oils (EO) from three plants - Cinnamomum camphora, Piper nigrum and Stemona japonica - were tested on Oryzaephilus surinamensis in the laboratory. Repellency was tested on filter paper in Petri dishes at a concentration of $31.4 \mu \mathrm{g} / \mathrm{cm}^{2}$, and 20 adults (10 days old) were observed for repellency behaviour 12, 24, 48 and 96 hours after the bioassay without any food. Cinnamomum camphora EO was the strongest repellent $(83.75 \pm 1.83 \%)$, followed by the Piper nigrum and Stemona japonica EOs. The eggs were obtained by maintaining 20 individuals (males and females) for $24 \mathrm{~h}$ in a $100 \mathrm{~mL}$ glass jar containing $5 \mathrm{~g}$ of diet feed. To evaluate the effect of $\mathrm{EO}$ on the development of larvae and adults, a filter paper disc impregnated with $0.1 \mathrm{~mL}$ of EO was placed on the inner side of the lid of the jar containing the eggs and diet feed. After 40 days, the number of adults and larvae in the jar was counted. All three EOs exhibited bioactivity against the development of larvae and adults. A relatively low number of larvae and adults was recorded in Cinnamomum camphora, followed by Stemona japonica and Piper nigrum. Gas chromatography/mass spectrometry was used to identify the major compounds in the EOs. Further studies are recommended to evaluate their bioactivity against different insect pests in stored seeds.
\end{abstract}

KEY WORDS: Essential oil, Chemical constituents, Bioactivity, Saw-toothed beetle.

* Corresponding author: wanluncai@163.com 


\section{INTRODUCTION}

Insect pests of stored grains are a constant problem, as they can damage and spoil them; they may cause losses of up to $40 \%$ worldwide (MATTHEWs 1993). The saw-toothed grain beetle, Oryzaephilus surinamensis (LINNAEUs, 1758) (Coleoptera: Silvanidae), is one of the most destructive and serious pests of grains stored in bulk. This insect infests every kind of stored product that is part of the human diet, including cereal grains, fast foods, seeds and nuts, and even dried meats (METCALF \& FLINT 1979, Rossiter et al. 2001, HASHEM et al. 2012).

Many fumigant chemicals have been introduced to manage this harmful pest. In fact, the first pyrethroid- and organophosphorus-based insecticides are still being used to protect stored foods and other agricultural commodities from infestation by this insect (KIM et al. 2003, PARK et al. 2003). With synthetic pesticides, the control of such pests is easy. Moreover, such chemicals are a part of modern life in protecting stored products, fields and gardens: pest-killing chemicals costing $\$ 38$ billion are applied worldwide every year (PANGERMANY 2012).

The abuse of these toxic chemicals for controlling agricultural and stored food pests has led to many environmental problems, including toxic effects on non-target organisms and resistance to chemicals among targeted insect species (COLLINS et al. 2005, JovANOVIĆ et al. 2007). These environmental issues have changed thinking among scientists and persuaded them to consider alternative methods (KoUL et al. 2008) of controlling insect pests. The use of plant extracts as alternatives to chemical pesticides has been found effective in managing many insect species (PINO et al. 2013): they are bioactive against many insect species, providing maximum repellency and toxicity as well as retarding feeding, oviposition and growth in crop fields, greenhouses and stores (ISMAN 2000, KOUL et al. 2008, CHAKIRA et al. 2017).

Many essential oils (EOs) are non-toxic to other organisms and effectively control target organisms; they are biodegradable and potentially useful in all types of integrated pest management (KIM et al. 2003). Researchers are currently extracting EOs from different plant species, but time is needed to identify the most effective plant EOs and to find the most suitable methods of applying these oils for controlling insect pests. It is hoped that the results will be beneficial in the race to find better control strategies for the saw-toothed grain beetle. Therefore, the present work was designed first to study adult repellency and then to observe the effect on larval and adult development in a fumigated area. EOs from three plants - Cinnamomum camphora (L.) J.PRESL. (Lauarceae), Piper nigrum L. (Piperaceae) and Stemona japonica (MIQ.) (Stemonaceae) - were tested against Oryzaephilus surinamensis. 


\section{MATERIALS AND METHODS}

\section{Insect culture}

The present research was carried out in the Hubei Insect Resources Utilization and Sustainable Pest Management Key Laboratory of Huazhong Agricultural University, China, during April-August 2016. Adult saw-toothed grain beetles were reared on a 70:30 mixture of wheat and maize flour containing $5 \%$ yeast in $250 \mathrm{~mL}$ glass jars covered with black muslin cloth to provide darkness and enough air for maximum reproduction. The jars containing the insects were kept in the laboratory at $25 \pm 2{ }^{\circ} \mathrm{C}$ with $50 \pm 5 \%$ relative humidity (RH) in a 14-10 light-dark (LD) regime.

\section{Ethanol-extracted botanical oils}

The plant materials for producing the EOs (small leaves with inflorescence of Zhang Ye (Cinnamomum camphora (L.) J.PRESL.), fully ripe seeds of white pepper (Piper nigrum L.) and roots of Baibu (Stemona japonica (MIQ.)) were purchased from a franchise registered with the Beijing Tongrentang Group, China. The oil extraction process was based on the methodologies of SU et al. (2009) and YAO et al. (2011). All the materials were cleaned, oven-dried, crushed to a powder and finally sieved through a 40-mm size mesh. One-gram samples of powder were mixed with $5 \mathrm{~mL}$ of $95 \%$ ethanol, after which they were incubated in a dark area for seven days at $20 \pm 5^{\circ} \mathrm{C}$. The mixtures were shaken twice a day to ensure that the powder was well mixed. They were then filtered through a Büchner funnel, and the filtrates stored at room temperature. The plant residue was again mixed (1 g powder $/ 2.5 \mathrm{~mL} \mathrm{95 \%} \mathrm{ethanol)} \mathrm{and} \mathrm{left} \mathrm{for} \mathrm{the} \mathrm{same} \mathrm{length} \mathrm{of} \mathrm{time} \mathrm{in} \mathrm{a} \mathrm{dark} \mathrm{place.} \mathrm{The}$ filtrates from the first and second extractions were combined and the solvent removed in a rotary evaporator. When the oil extracts were quite dry, each sample was weighed (the original $155.85 \mathrm{~g}$ of Cinnamomum camphora powder yielded a final oil mass of $25.21 \mathrm{~g}$, $604 \mathrm{~g}$ of Piper nigrum powder yielded a final oil mass of $47.49 \mathrm{~g}$, and $400.91 \mathrm{~g}$ of Stemona japonica powder yielded a final oil mass of $26.53 \mathrm{~g}$ ). The crude oils were collected in brown bottles and placed in a refrigerator at $4{ }^{\circ} \mathrm{C}$. Before starting the bioassay, the crude oils were dissolved separately in dimethyl sulphoxide (DMSO): $0.05 \mathrm{~g}$ oil + 0.3 mL DMSO $+1 \%$ Tween-20 distilled water $=50 \mathrm{~mL}$ with a $10,000 \mathrm{ppm}$ concentration. This concentration was used as the working solution in the bioassay.

\section{Identification of the Chemical Components of the Essential Oil}

The chemical components of each EO were identified by gas chromatography-mass spectrometry on a Varian 450-GC/320-MS (Varian, Inc., Walnut Creek, California) according to WAGAN et al. (2017a). An HP-5MS capillary column (film thickness: $30 \mathrm{~m}$ length $\times 0.25 \mathrm{~mm}$ inner diameter) was used, and the compounds were detected with a flame 
ionization detector. For gas chromatography, the injector oven temperature was initially maintained at $60^{\circ} \mathrm{C}$ for $3 \mathrm{~min}$, ramped at $10^{\circ} \mathrm{C} / \mathrm{min}$ to $180^{\circ} \mathrm{C}$ and maintained for $1 \mathrm{~min}$, and ramped again at $20^{\circ} \mathrm{C} / \mathrm{min}$ to $280{ }^{\circ} \mathrm{C}$ and maintained for $15 \mathrm{~min}$. One microlitre of the samples diluted with $1 \%$ hexane was injected with a split ratio of $1: 10$. The column pressure was maintained at $100 \mathrm{kPa}$. Helium gas, passed at a rate of $1.0 \mathrm{~mL} / \mathrm{min}$, was used as the sample carrier. The temperatures of the MS quadrupole, ion source and transmission line were 150,230 , and $250{ }^{\circ} \mathrm{C}$, respectively. Chemical constituents were identified from the gas chromatogram with the online libraries of Wiley, REPLIB, MANLIB, and PMWTox3N (NIST 2011).

\section{Repellency test in the laboratory}

The repellency assay was performed according to a modified version of the methodology of TAPONDJOU et al. (2005). A $9 \mathrm{~cm}$ filter paper disc was used: half of each disc was uniformly treated with $0.1 \mathrm{~mL}$ of the working solution, while the other half was treated with DMSO + Tween-20 solution, to obtain a final concentration of $31.4 \mu \mathrm{g} / \mathrm{cm}^{2}$ of each one (the working solution and the DMSO + Tween-20 solution). The filter papers were dried for one hour following application of the solution and then placed in a $9 \mathrm{~cm}$ Petri dish. Twenty 10-day-old adults of Oryzaephilus surinamensis were released at the centre of the filter paper disc in the Petri dish, and covered with a lid with four small holes to allow the extra fumes from the paper disc to escape. All the Petri dishes were covered with black cloth and kept in the same room that had been used for the rearing. Insect repellency was recorded by counting the number of insects in both parts 12, 24, 48 and 96 $\mathrm{h}$ after insect release. The experiment was repeated eight times.

\section{Larval and adult development following essential oil fumigation}

Twenty ten-day-old adults (10 males and 10 females) were released for $24 \mathrm{~h}$ for oviposition in a $100 \mathrm{~mL}$ airtight glass jar containing a 70:30 mixture of wheat and maize flour and $5 \%$ yeast. $0.1 \mathrm{~mL}$ of the working solution was applied to a $6 \mathrm{~cm}$ filter paper disc and the same volume of DMSO + Tween-20 + distilled water as control. After oviposition in the flour, the adults were isolated and the filter papers were attached to the cap of the glass jar. The jars were covered with caps and kept in the same environment as had been used for rearing. To observe the larvae and adult emergence in flour, this was checked 40 days after insect isolation by putting flour in Petri dishes and adding water. The flour was mixed with water and left for $1 \mathrm{~min}$, after which the Petri dishes were observed under a microscope and the number of larvae and adults recorded. A total of eight replicates were performed for each EO. 


\section{Data analysis}

The percentage repellency was calculated using the equation PR $(\%)=[(\mathrm{C}-$ $\mathrm{T}) /(\mathrm{C}+\mathrm{T})] \times 100$ according to LIU et al. (2013), where PR stands for the percentage repellency, $\mathrm{C}$ is the number of individuals in the control, and $\mathrm{T}$ is the number of individuals in the treated area. The chi-squared goodness-of-fit test was used to compare the treatment and control parts in the Petri dishes. Paired t-tests were used to compare the mean numbers of insects in the treated and control areas. Mean percentage repellency (PR) among the oils was analysed by ANOVA and Tukey's post hoc test with a significance level of $P<0.05$. The percentage data were arcsine-square root transformed, and all count data were square root $(x+1)$ or $\log 10(x+1)$ transformed before being subjected to data analysis. The untransformed means are presented in the results. The whole statistical analysis was performed using SPSS (version 20).

\section{RESULTS}

\section{Chemical composition of the three essential oils}

The main chemical components in the EOs were identified by GC-MS. Twenty-three major chemical components were found in the three EOs: 1) Stemona japonica (9): 4vinylphenol; 5-hydroxymethyl-2-furancarboxaldehyde; dl-stenine; 9,10anthracenedicarbonitrile; 1-tert-butyl-5-methoxy-2,2-dimethylindan; benzo[a]naphthacene; methyl 4,5,7-trimethoxy-2-naphthoate; stemonine; syn-7-benzhydrylbicyclo[2.2.1]heptane); 2) Piper nigrum (6): trans(beta)-caryophyllene; 9-octadecenoic acid; hexadecenenitrile; pyrrolidine, 1-(1-oxo-11-octadecenyl); piperine; 2-(M-tolyl)-2-oxazoline); 3) Cinnamomum camphora (8): linalol; trans-caryophyllene; alpha-humulene; nerolidol; 1,5-heptadien-4one, 3,3,6-trimethyl acetic acid; 2-propanol, 1-chloro, phosphate; phytol; ethyl linoleolate. The chemical components of EOs, their total percentages and retention times are listed in Table 1.

\section{Adult repellency}

The results of the Petri dish test showed strong repellency up to 96 hours against adult stages of Oryzaephilus surinamensis after the bioassay. ANOVA did not reveal any significant difference between the three EOs, but all treatments were significantly different compared with the control at $12 \mathrm{~h}(\mathrm{~F}=8.02, \mathrm{df}=3,28, P=0.00), 24 \mathrm{~h}(\mathrm{~F}=114.91, \mathrm{df}=3$, $28, P=0.00), 48 \mathrm{~h}(\mathrm{~F}=84.32, \mathrm{df}=3,28, P=0.00)$, and $96 \mathrm{~h}(\mathrm{~F}=38.66, \mathrm{df}=3,28, P=$ 0.00) after insect release (Fig. 1). Repellency caused by Cinnamomum camphora EO was strong in the area preference method in Petri dishes. This EO can provide a maximum repellency of up to $83.75 \pm 1.83 \%$ (Fig 1). C. camphora EO exhibited significant 
differences when compared with the corresponding control at $12 \mathrm{~h}\left(\chi^{2}=68.04\right.$, $\mathrm{df}=1, P=$ $0.00), 24 \mathrm{~h}\left(\chi^{2}=54.42, \mathrm{df}=1, P=0.00\right), 48 \mathrm{~h}\left(\chi^{2}=52.36, \mathrm{df}=1, P=0.00\right)$ and $96 \mathrm{~h}\left(\chi^{2}=\right.$ 48.41, $\mathrm{df}=1, P=0.00$ ) after the bioassay (Fig. 2).

Table 1. Chemical components identified in EOs based on GC-MS analysis. RT - retention time, \% - \% of total, Quant. - Quantity (mg) per $100 \mathrm{~g}$.

\begin{tabular}{|c|c|c|c|}
\hline Chemical components of essential oils & RT & $\%$ & Quant. \\
\hline \multicolumn{4}{|c|}{ Stemona japonica } \\
\hline 4-vinylphenol & 8.40 & 0.28 & 280 \\
\hline 5-hydroxymethyl-2-furancarboxaldehyde & 8.53 & 0.68 & 680 \\
\hline dl-stenine & 14.17 & 0.90 & 900 \\
\hline 9,10-anthracenedicarbonitrile & 16.26 & 0.36 & 360 \\
\hline 1-tert-butyl-5-methoxy-2,2-dimethylindan & 17.59 & 7.59 & 7590 \\
\hline benzo[a]naphthacene & 21.13 & 1.56 & 1560 \\
\hline methyl 4,5,7-trimethoxy-2-naphthoate & 21.55 & 5.69 & 5690 \\
\hline stemonine & 22.33 & 31.25 & 31250 \\
\hline syn-7-benzhydrylbicyclo[2.2.1]heptane & 23.28 & 3.31 & 3310 \\
\hline \multicolumn{4}{|c|}{ Piper nigrum } \\
\hline trans(beta)-caryophyllene & 10.13 & 2.48 & 2480 \\
\hline 9-octadecenoic acid & 15.23 & 1.06 & 1060 \\
\hline hexadecenenitrile & 15.38 & 1.90 & 1900 \\
\hline pyrrolidine, 1-(1-oxo-11-octadecenyl) & 19.03 & 1.53 & 1530 \\
\hline piperine & 20.88 & 34.75 & 34750 \\
\hline 2-(M-tolyl)-2-oxazoline & 21.22 & 2.71 & 2710 \\
\hline \multicolumn{4}{|c|}{ Cinnamomum camphora } \\
\hline linalol & 7.65 & 0.72 & 720 \\
\hline trans-caryophyllene & 10.23 & 2.82 & 2820 \\
\hline alpha-humulene & 10.46 & 0.98 & 980 \\
\hline nerolidol & 10.98 & 12.18 & 12180 \\
\hline 1,5-heptadien-4-one, 3,3,6-trimethyl acetic acid & 12.00 & 59.94 & 59940 \\
\hline 2-propanol, 1-chloro, phosphate & 12.33 & 1.27 & 1270 \\
\hline phytol & 13.88 & 1.02 & 1020 \\
\hline ethyl linoleolate & 14.15 & 0.77 & 770 \\
\hline
\end{tabular}

Note: the chemical components of Stemona japonica were described by WAGAN et al. (2016), and those of Piper nigrum were described by WAGAN et al. (2017b). 

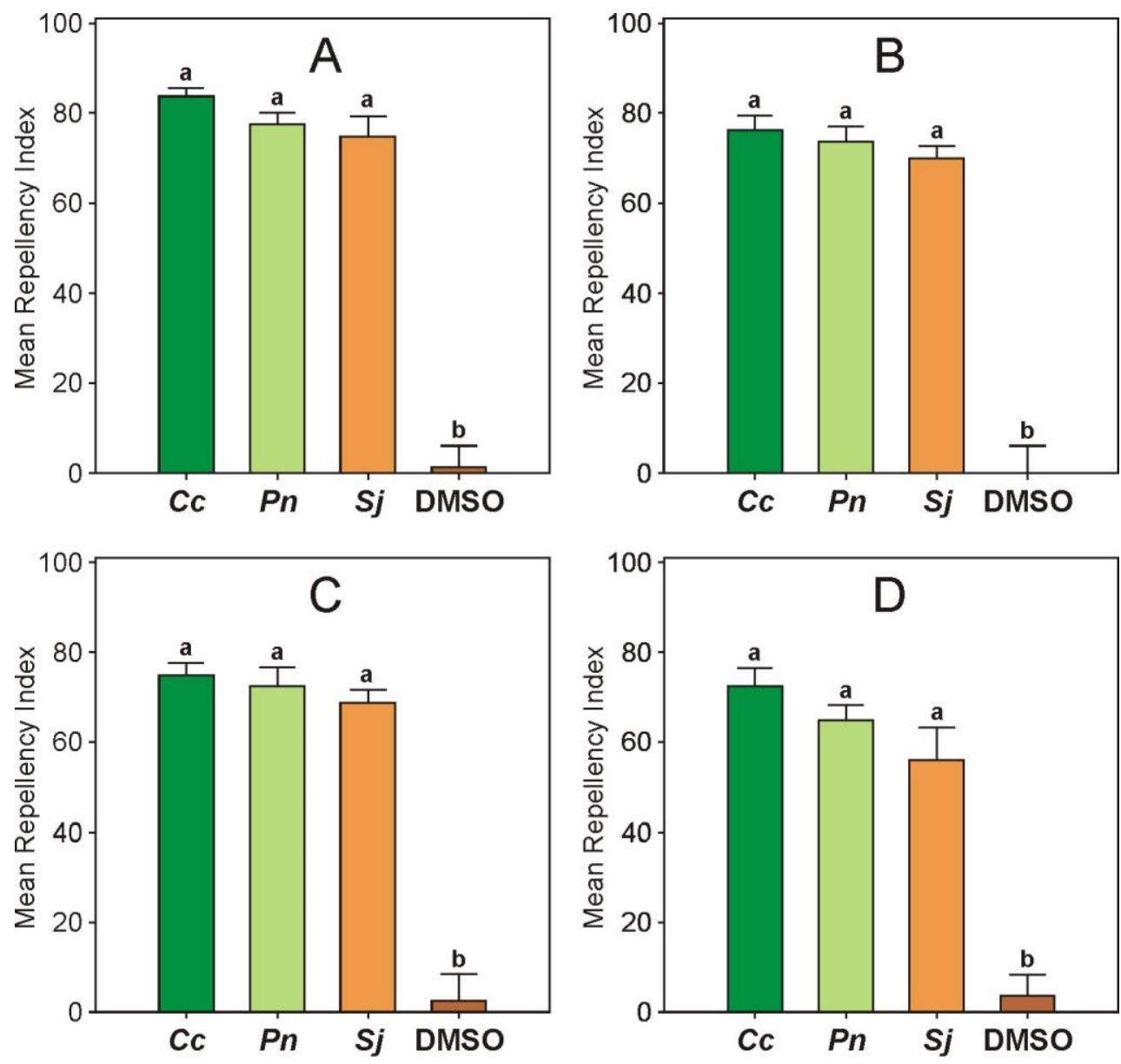

Fig. 1. Percentage (Mean $\pm \mathrm{SE}$ ) repellency of saw-toothed grain beetles, A: $12 \mathrm{~h}$ after insect release, B: $24 \mathrm{~h}$ after insect release, C: $48 \mathrm{~h}$ after insect release, D: $96 \mathrm{~h}$ after insect release. Cc - Cinnamomum camphora, Pn - Piper nigrum, Sj-Stemona japonica. The mean numbers of adults were analysed by ANOVA at a significance level of $P<0.05$.

The repellency caused by the Piper nigrum EO was the second strongest after $12 \mathrm{~h}$ and $96 \mathrm{~h}$ of bioassay, and the third strongest after 24 and $48 \mathrm{~h}$ of bioassay (Fig. 1). This oil gave a peak repellency of up to $77.50 \pm 2.50 \%$ in the area preference test, but its repellency decreased with time (Fig. 1). The chi-squared test revealed a significant difference between $P$. nigrum EO and its corresponding control at $12 \mathrm{~h}\left(\chi^{2}=56.54, \mathrm{df}=1, P=0.00\right), 24 \mathrm{~h}\left(\chi^{2}=\right.$ 44.67, $\mathrm{df}=1, P=0.00), 48 \mathrm{~h}\left(\chi^{2}=42.88, \mathrm{df}=1, P=0.00\right)$ and $96 \mathrm{~h}\left(\chi^{2}=37.72, \mathrm{df}=1, P=\right.$ 0.00 ) after the bioassay (Fig. 2). 

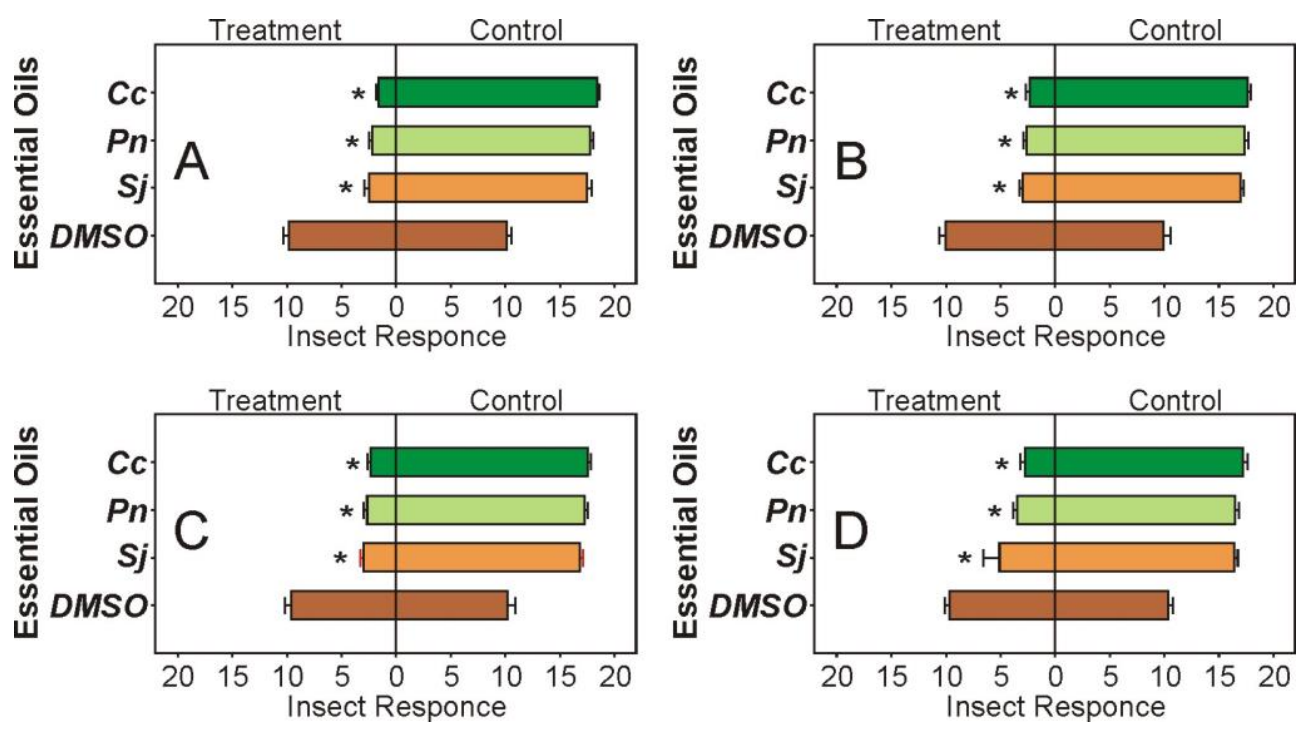

Fig. 2. Mean number and SE of larvae and adults of saw-toothed grain beetles, A: $12 \mathrm{~h}$ after insect release, B: $24 \mathrm{~h}$ after insect release, C: $48 \mathrm{~h}$ after insect release, D: $96 \mathrm{~h}$ after insect release. Cc - Cinnamomum camphora, Pn - Piper nigrum, Sj-Stemona japonica. The mean numbers of adults were analysed by the chi-squared test at the significance level $P<0.05$.

A peak percentage repellency of $75.00 \pm 4.23 \%$ was recorded with the Stemona japonica EO $12 \mathrm{~h}$ after insect release. The percentage repellency of S. japonica oil decreased with time, like that of the other EOs (Fig. 1). In comparison with the control, however, it exhibited significant differences at $12 \mathrm{~h}\left(\chi^{2}=52.36, \mathrm{df}=1, P=0.00\right), 24 \mathrm{~h}\left(\chi^{2}=\right.$ 50.36, $\mathrm{df}=1, P=0.00), 48 \mathrm{~h}\left(\chi^{2}=48.41, \mathrm{df}=1, P=0.00\right)$ and $96 \mathrm{~h}\left(\chi^{2}=37.88, \mathrm{df}=1, P=\right.$ 0.00 ) after the bioassay (Fig. 2).

No repellency was caused by DMSO (the solvent for the EOs), nor was any significant difference observed between DMSO and the negative control at $12 \mathrm{~h}\left(\chi^{2}=0.01, \mathrm{df}=1, P=\right.$ $0.91), 24 \mathrm{~h}\left(\chi^{2}=0.00, \mathrm{df}=1, P=1.00\right), 48 \mathrm{~h}\left(\chi^{2}=0.05, \mathrm{df}=1, P=0.82\right)$ and $96 \mathrm{~h}\left(\chi^{2}=\right.$ 0.11 , df $=1, P=0.74$ ) after the bioassay. DMSO remained neutral as regards repellency against adult $O$. surinamensis (Fig. 2). 


\section{Larvae and adult development in the fumigation with essential oils}

The results showed that both larval developmental stages and adults were affected by all the EOs. One-way ANOVA between EOs and the control showed a significant difference in larval development $(\mathrm{F}=3.45, \mathrm{df}=3,28, P=0.03)$ and adult development $(\mathrm{F}=41.24, \mathrm{df}=$ $3,28, P=0.00$ ) after 40 days of the bioassay (Fig. 3).
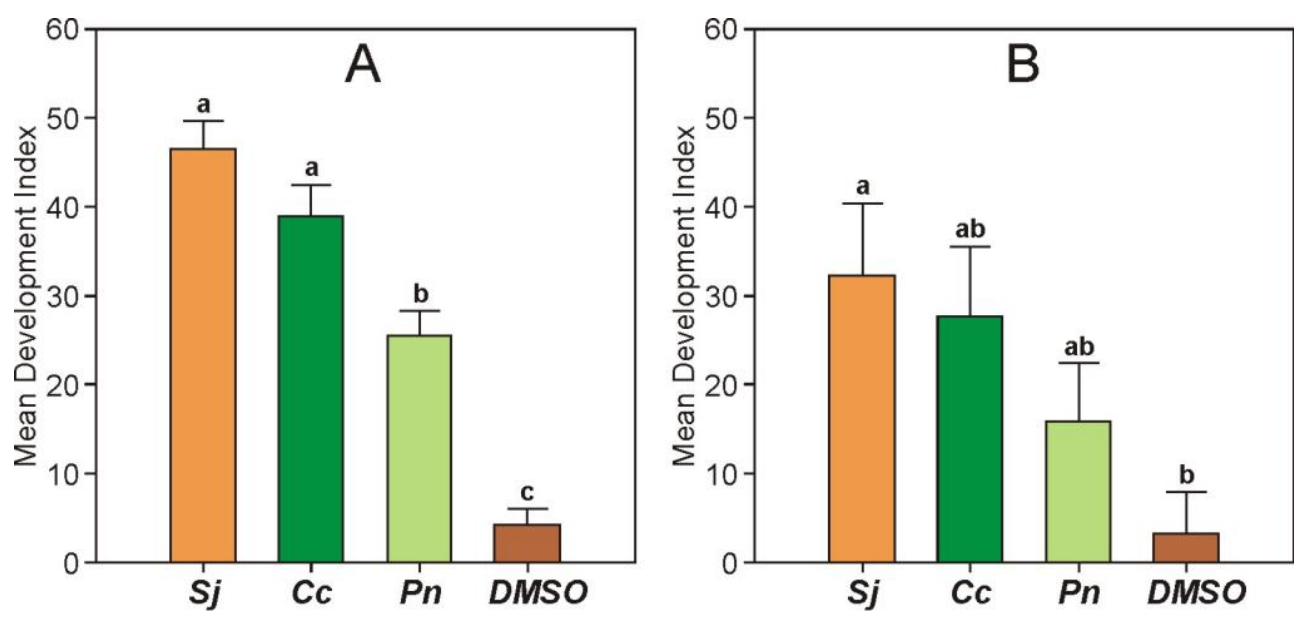

Fig. 3. Percentage (Mean $\pm \mathrm{SE}$ ) of larval and adult development of saw-toothed grain beetles, A: development of larvae after 40 days, B: development of adults after 40 days. $\mathrm{Cc}$ - Cinnamomum camphora, $\mathrm{Pn}$ - Piper nigrum, $\mathrm{Sj}$ - Stemona japonica. The mean numbers were analysed by ANOVA at a significance level of $P<0.05$.

To confirm the fumigation effects on larval and adult development, EOs were compared with the controls. A t-test analysis revealed significant differences between Stemona japonica and the control in larval $(\mathrm{t}=3.91, \mathrm{df}=7, P=0.01)$ and adult $(\mathrm{t}=11.18, \mathrm{df}=7, P$ $=0.00$ ) development after 40 days of the bioassay (Fig. 4). The same observations were made with the Cinnamomum camphora EO in the larval developmental stages $(\mathrm{t}=3.69$, df $=7, P=0.01)$ and adults $(\mathrm{t}=9.05, \mathrm{df}=7, P=0.00)$ after 40 days of the bioassay (Fig 4). However, only Piper nigrum displayed a significant difference with respect to adult development $(\mathrm{t}=7.87, \mathrm{df}=7, P=0.00)$, and there were no significant differences in larval development $(\mathrm{t}=2.05, \mathrm{df}=7, P=0.08)$ (Fig. 4). To confirm the effect of DMSO on larval and adult stages, DMSO was compared with a negative control. The results of the t-test analysis between DMSO and the control revealed no significant differences for the larval developmental stages $(\mathrm{t}=0.76, \mathrm{df}=7, P=0.47)$ or adults $(\mathrm{t}=2.17, \mathrm{df}=7, P=0.07)$ after the 40-day bioassay (Fig. 4). 

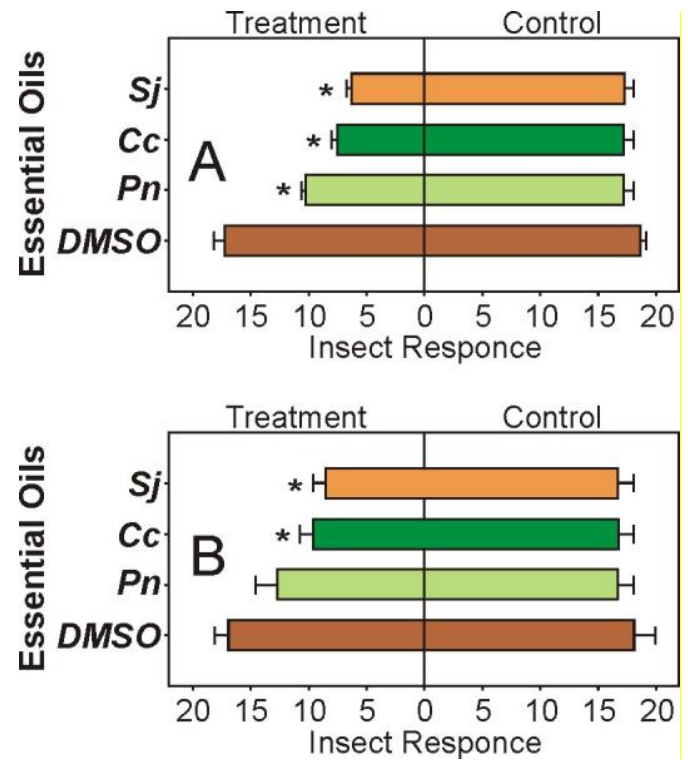

Fig. 4. Mean number and SE of larvae and adults of saw-toothed grain beetle, A: $12 \mathrm{~h}$ after insect release, B: $24 \mathrm{~h}$ after insect release, C: $48 \mathrm{~h}$ after insect release, D: after $96 \mathrm{~h}$ after insect release. Cc - Cinnamomum camphora, Pn - Piper nigrum, Sj-Stemona japonica. The mean numbers of adults were analysed by chi-square test at the significance level $P<0.05$.

\section{DISCUSSION}

The results of our study have shown that repellency caused by all the EOs against Oryzaephilus surinamensis remains strong up to 96 hours after the bioassay. The Cinnamomum camphora EO demonstrated a maximum repellency of up to $96 \mathrm{~h}$ in the area preference method. AL-JABR (2006) obtained positive results with C. camphora EO: it produced a $39.46 \%$ repellency against Oryzaephilus surinamensis in a concentration of $1 \%$ and a $37.04 \%$ repellency against Trobolium castaneum (J.F.W. HERBST, 1797) in a concentration of $0.75 \%$ in the lab experiment. Essential oil from the seeds of Cinnamomum camphora exhibited a maximum repellency up to $89.86 \%$ after $24 \mathrm{~h}$ of a bioassay at a concentration of $20 \mu \mathrm{L} / \mathrm{mL}$ against cotton aphids (JIANG et al. 2016). In our experiment, the C. camphora EO exhibited the strongest repellency against Oryzaephilus surinamensis of all the EOs; its repellency decreased as time passed. 
The essential oil from Piper nigrum was the second strongest repellent in the area test. Its repellency was the second highest after $12 \mathrm{~h}$ and $96 \mathrm{~h}$, and the third highest after 24 and $48 \mathrm{~h}$ of the assay. Essential oils from many plant species have exhibited toxic, repellent and antifeedant activities against many insect species, especially stored product pests such as Oryzaephilus surinamensis and Tribolium castaneum (KIM et al. 2003, WAGAN et al. 2016, 2017a). A repellency bioassay was conducted on filter paper to observe its repellency on $T$. castaneum adults; the results showed that the EO of $P$. nigrum repelled $T$. castaneum adults at a minimum concentration of $0.2 \%$ (CHAUBEY 2007).

Our results showed that the EO of Stemona japonica strongly repelled adults until the last observation. The repellency of $S$. japonica EO was the third strongest after $12 \mathrm{~h}$ and 96 $\mathrm{h}$ and the second strongest after $24 \mathrm{~h}$ and $48 \mathrm{~h}$ of the bioassay. Similar results were found by WAGAN et al. (2016a), who showed that $S$. japonica EO had a repellent effect against Tribolium castaneum adults up to $72 \mathrm{~h}$ at a concentration of $10000 \mathrm{ppm}(31.4 \mu \mathrm{g} / \mathrm{cm} 2)$ in laboratory conditions. Essential oil from Stemona japonica was found to be a good agent for controlling the greenhouse whitefly: it displayed contact and fumigant toxicity towards adults and anti-oviposition properties against female whiteflies (WAGAN et al. 2016b).

All the EOs were active against adults and the larval developmental stages. S. japonica showed maximum anti-emergence and anti-developmental activity against adults and larvae after 40 days of the bioassay. It has been confirmed that the genus Stemona LouR. possesses insecticidal activity against Spodoptera littoralis (BOISDUVAL, 1833) (BREM et al. 2002), and that an extract from Stemona is effective against mosquito larvae (LEE $\&$ CHIANG 1994). Cinnamomum camphora EO effectively reduced the numbers of larvae and adults. The $\mathrm{EO}$ of the genus Cuminum L. (C. cyminum L.) was toxic to the larval stages and adults, and it reduced the oviposition rate and effect on the development of larvae to pupae as well as pupae to adult for Tribolium castaneum (CHAUBEY 2007). We obtained similar results with the genus Cinnamomum against the developmental stages of Oryzaephilus surinamensis.

In our study, the EO from Piper nigrum exhibited repellency activity against adults. $P$. nigrum EO displayed repellency and toxicity against Tribolium castaneum and retarded its development (UPADHYAY \& JAISWAL 2007). According to our results, we can state that for the first few days its fumigation was effective and that a few larvae survived; after a few days, however, its impact diminished and the larval survival rate was higher. Therefore, no significant difference was observed as compared with control.

To the best of our knowledge, no previous reports on the bioactivity of Stemona japonica, Piper nigrum and Cinnamomum camphora EOs against Oryzaephilus surinamensis have been published. Essential oils are chemically characterized as natural mixtures of components, which can be bioactive against many insect species. Earlier studies on the major compounds of EO in Cinnamomum camphora, Piper nigrum and 
Stemona japonica revealed their bioactivities against several species. BREM et al. (2002) demonstrated the repellent activity of tubero-stemonine against the larvae of Spodoptera littoralis. 4-Vinylphenol is toxic to rats and mice (GERTSCH et al. 2008). Caryophyllene is selectively effective against rodents, exhibiting cannabimimetic anti-inflammatory effects, especially in mice (GERTSCH et al. 2008) but also in rats (JAVED et al. 2016). Furthermore, piperine demonstrated significant analgesic, antipyretic and anti-ulcerogenic activities against mice at doses 20 and $30 \mathrm{mg} / \mathrm{kg}$ (SABINA et al. 2010). Nerolidol is known to cross the plasma membrane and interfere with cell proteins; it has been reported to exhibit antifungal, antimicrobial, anticancer and antioxidant bioactivities (CHAN et al. 2016). Humulene, which occurs naturally in aromatic plants, displayed anti-inflammatory activity in in vitro studies (FERNANDES et al. 2007). Phytol exhibited an anticonvulsant effect in mice, thus protecting them from epilepticus and decreasing their mortality rate (COSTA et al. 2012). Linalol has been used as a pesticide against insects, such as fruit flies, fleas and cockroaches (YANG et al. 2004). All these studies have demonstrated that the chemical compounds in the EOs of Cinnamomum camphora, Piper nigrum and Stemona japonica have repellent and fumigant activities. The present study showed that the chemical compounds present in the EOs of these species also exhibit bioactivity against insect pests.

All the EOs were strongly repellent against adults of Oryzaephilus surinamensis in the area preference tests up to $96 \mathrm{~h}$ of the bioassay. Cinnamomum camphora was the strongest repellent, followed by Piper nigrum and Stemona japonica. All EOs were bioactive against larvae and adults. The lowest number of larvae and adults were recorded in S. japonica EO followed by Cinnamomum camphora and Piper nigrum after 40 days of the bioassay. Further research is recommended on the chemical components of these oils and tests will be conducted in different seed stores.

\section{REFERENCES}

AL-JABR A.M. 2006. Toxicity and Repellency of Seven Plant Essential Oils to Oryzaephilus surinamensis (Coleoptera: Silvanidae) and Tribolium castaneum (Coleoptera: Tenebrionidae). Scientific Journal of King Faisal University (Basic and Applied Sciences), 7 (1): 49-60.

Brem B., Seger C., Pacher T., Hofer O., Vajrodaya S., Greger H. 2002. Feeding deterrence and contact toxicity of Stemona alkaloids. A source of potent natural insecticides. Journal of Agricultural and Food Chemistry, 50 (22): 6383-6388.

Chakira H., Long M., Liu S., Zhao J., He Y.P., Wagan T.A., Hua H.X. 2017. Repellency of essential oils against Nephotettix cincticeps: laboratory and green house assays. Journal of Applied Entomology, 141 (9): 708-720.

Chan W.K., Tan L.T., Chan K.G., Lee L.H., Goh B.H. 2016. Nerolidol: A sesquiterpene alcohol with multi-faceted pharmacological and biological activities. Molecules, 21 (5): 529. 
Chaubey M.K. 2007. Toxicity of essential oils from Cuminum cyminum (Umbelliferae), Piper nigrum (Piperaceae) and Foeniculum vulgare (Umbelliferae) against stored-product beetle Tribolium castaneum HERBST (Coleoptera: Tenebrionidae). Electronic Journal of Environmental, Agricultural and Food Chemistry, 6 (1): 1719-1727.

Collins P.J., Daglish G.J., Pavic H., KopitTKe R.A. 2005. Response of mixed age cultures of phosphine-resistant and susceptible strains of lesser grain borer, Rhyzopertha dominica, to phosphine at a range of concentrations and exposure periods. Journal of Stored Product Research, 41 (4): 373-385.

Costa J.P., Ferreira P.B., De Sousa D.P., Jordan J., Freitas R.M. 2012. Anticonvulsant effect of phytol in a pilocarpine model in mice. Neuroscience Letters, 523 (2): 115-118.

Fernandes E.S., Passos G.F., Medeiros R., Da Cunha F.M., Ferreira J., Campos M.M., PiAnOwSKi L.F., CALIXTO J.B. 2007. Anti-inflammatory effects of compounds alpha-humulene and (-)-trans-caryophyllene isolated from the essential oil of Cordia verbenacea. European Journal of Pharmacology, 569 (3): 228-236.

Gertsch J., Leonti M., Raduner S., Racz I., Chen J.Z., Xie X.Q., Altmann, K.H., Karsak M., Zimmer A. 2008. Beta-caryophyllene is a dietary cannabinoid. Proceeding of the National Academy of Science of the United States of America, 105 (26): 9099-9104.

Hashem M.Y., Ahmed S.S., El-Mohandes M.A., Gharib M.A. 2012. Susceptibility of different life stages of saw-toothed grain beetle Oryzaephilus surinamensis (L.) (Coleoptera: Silvanidae) to modified atmospheres enriched with carbon dioxide. Journal of Stored Product Research, 48: $46-51$.

Isman M.B. 2000. Plant essential oils for pest and disease management. Crop Protection, 19 (8-10): 603-608.

Javed H., Azimullah S., Haque M.E., Ojha S.K. 2016. Cannabinoid type 2 (cb2) receptors activation protects against oxidative stress and neuroinflammation associated dopaminergic neurodegeneration in rotenone model of Parkinson's disease. Frontiers in Neuroscience, 10: 321.

Jiang H., WANG J., Song L., CaO X., YaO X., TANG F., YUE Y. 2016. GC^GC-TOFMS Analysis of Essential Oils Composition from Leaves, Twigs and Seeds of Cinnamomum camphora L. PRESL and Their Insecticidal and Repellent Activities. Molecules, 21 (4): 1-12.

Jovanović Z., Kostić M., Popović Z. 2007. Grain-protective properties of herbal extracts against the bean weevil Acanthoscelides obtectus SAY. Industrial Crop and Products, 26 (1): 100-104.

Kiм S., PARK C., Онн M.H., Сно H.C., AHN Y.J. 2003. Contact and fumigant activities of aromatic plant extracts and essential oils against Lasioderma serricorne (Coleoptera: Anobiidae). Journal of Stored Products Research, 39 (1): 11-19.

Koul O., Walia S., Dhaliwal G.S. 2008. Essential oils as green pesticides: potential and constraints. Biopesticides International, 4 (1): 63-84.

LEE H.L. ChiAnG Y.F. 1994. Insecticidal activity of the herbal plant, Stemona tuberosa Lour to mosquito larvae. Tropical Biomedicine, 11 (1): 87-89.

Liu X.C., Li Y.P., Li H.Q., Deng Z.W., Zhou L., Liu Z.L., Du S.S. 2013. Identification of Repellent and Insecticidal Constituents of the Essential Oil of Artemisia rupestris L. Aerial Parts against Liposcelis bostrychophila BADONNEL. Molecules, 18 (9): 10733-10746. 
Matthews G.A. 1993. Insecticide application in stores. [in:] G.A. Matthews, E.C. HisloP (eds). Application technology for crop protection CAB, London, 305-315.

MetCalf C.L., Flint W.P. 1979. Destructive and useful insects. Tata McGraw-Hill Pub. Com. Ltd., New Delhi.

NIST [NIST/EPA/NIH Mass Spectral Database] 2011 and NIST Mass Spectral Search Program (Version 2.0g) 2011. U.S. Department of Commerce National Institute of Standards and Technology Standard Reference Data Program Gaithersburg, MD 20899.

Pan-Germany 2012. Pesticide and health hazards. Facts and figures. 1-16. Internet: (www.pangermany.org/download/Vergift_EN-201112-web.pdf)

PARK C., LeE S.G., ChOI D.H., PARK J.D., AhN Y.J. 2003. Insecticidal activities of constituents identified in the essential oil from leaves of Chamaecyparis obtusa against Callosobruchus chinensis (L.) and Sitophilus oryzae (L.). Journal of Stored Products Research, 39 (4): 375-384.

Pino O., SÁNCheZ Y., RoJAS M.M. 2013 Plant secondary metabolites as an alternative in pest management. I: Background, research approaches and trends Revista de Protección Vegetal, 28 (2): 81-94.

Rossiter L.C., GunNing R.V., Rose H.A. 2001. The use of polyacrylamide gel-electrophoresis for the investigation and detection of fenitrothion and chlorpyrifos-methyl resistance in Oryzaephilus surinamensis (Coleoptera: Silvanidae). Pesticide Biochemistry Physiology, 69 (1): 27-34.

SABinA E.P., SouriYAn A.D.H., JACKLINE D., RASOOL M.K. 2010. Piperine, an active ingredient of black pepper attenuates acetaminophen-induced hepatotoxicity in mice. Asian Pacific Journal of Tropical Disease, 3 (12): 971-976.

SU Y.P., YANG C.J., HuA H.X., CAI W.L., LiN Y.J. 2009. Bioactivities of Ethanol Extracts from Thirteen Plants against Nilaparvata lugens (STÅL). Chinese Agricultural Science Bulletin, 25 (1): 198-202.

TAPONDJou L.A., Adler C., Fontem D.A., Bouda H., Reichmuth C.H. 2005. Bioactivities of cymol and essential oils of Cupressus sempervirens and Eucalyptus saligna against Sitophilus zeamais MotsChULSKY and Tribolium confusum DU VAL. Journal of Stored Products Research, 41 (1): 91-102.

Upadhyay R.K., Jaiswal G. 2007. Evaluation of biological activities of Piper nigrum oil against Tribolium castaneum. Bulletin of Insectology, 60 (1): 57-61.

Wagan T.A., ChakiRa H., Hua H.X., He Y.P., Zhao J. 2017b. Biological activity of essential oil from Piper nigrum against nymphs and adults Blattella germanica (Blattodea: Blattellidae). Journal of the Kansas Entomological Society, 90 (1): 1-9.

Wagan T.A., He Y.P., Cai W.L., Zhao J., Hua H.X. 2016b. Fumigant and contact toxicity and oviposition deterrent effects of plant essential oils on Bemisia tabaci (Hemiptera: Aleyrodidae). Florida Entomologist, 99 (4): 673-677.

Wagan T.A., Hu D.B., He Y.P., Nawaz M., NaziR T., Mabubu J.I., Hua H.X. 2016a. Repellency of three plant-derived essential oils against red flour beetle Tribolium castaneum (HERBST) (Coleoptera: Tenebrionidae). Turkish Journal of Entomology, 40 (4): 347-354.

Wagan T.A., Wang W.J., Hua H.X., CaI W.L. 2017a. Chemical constituents and toxicity, repellency, and oviposition deterrence effects of ethanol-extracted Myristica fragrans oil against Bemisia tabaci GENNADIUS (Hemiptera: Aleyrodidae). Florida Entomologist, 100 (3): 594-601. 
Yang Z., Bengtsson M., WitzGall P. 2004. Host plant volatiles synergize response to sex pheromone in codling moth, Cydia pomonella. Journal of Chemical Ecology, 30 (3): 619-629.

Yao Y.J., Liang Y.Y., Wang L.Q., Zhang W., YAnG C.J., Lin Y.J., HuA H.X. 2011. Control effect of extract and compound of Acorus gramineus against Nilaparvata lugens. Chinese Journal of Applied Entomology, 48 (2): 463-467.

Received: 3 July 2018

Accepted: 12 January 2019 